\title{
Clinical and experimental knowledge of photobiomodulation in accelerated orthodontics: A review
}

\section{Conocimiento clínico y experimental de la fotobiomodulación en ortodoncia acelerada: Una revisión}

\author{
Juan Eduardo Gomez Vázquez ${ }^{1}$ (D) | Olin Guadalupe Montero Jiménez ${ }^{1}$ (D) Jair Rodríguez Zarate $^{1}$ (D) \\ Daniela Orozco Jiménez $^{1}$ (D) María Fernanda García Vega $^{1}$ (D) Miguel Ángel Casillas Santana $^{1}$ (D).
}

\section{f ACCESO ABIERTO \\ ${ }^{1}$ Benemérita Universidad Autónoma de Puebla, Facultad de Estomatologia, Department of Orthodontics, Puebla, México.}

\begin{abstract}
Background: In recent years, there has been an increasing interest in finding a noninvasive method to induce the acceleration of dental movement, methods such as low intensity vibrations, pulsed electromagnetic fields, and lowlevel laser therapy (LLLT). There have been multiple studies on the efficacy of LLLT in animal models, in vitro and in patients without conclusive results.

Objective: Evaluate the state of the art on the use of LLLT to increase the rate of the orthodontic tooth movement to create a concise reference guide of the different laser and protocols available. Materials and Methods: The authors searched electronic databases (MedLine, Scopus and Semantic Scholar) for articles that evaluated the effects of low-lever laser therapy on the orthodontic tooth movement. Screening was performed at the title/ abstract and full-text level. Data extraction and quality assessment were performed by two reviewers independently. The reference lists of relevant studies were also screened for further relevant literature.

Results: We found conflicting information as to the efficacy of LLLT to accelerate the orthodontic tooth movement (OTM). There is no consensus in the way the irradiation should be performed.

Conclusions: The lack of a standardized irradiation protocol makes it hard to compare conflicting results, even in
\end{abstract} cases where the laser have the same technical specifications.

\section{KEYWORDS}

LLLT; OTM; Orthodontic Tooth Movement; GaAlAs Lasers; acceleration.

\section{RESUMEN}

Antecedentes: En los últimos años, ha habido un interés creciente en encontrar un método no invasivo para inducir la aceleración del movimiento dental, métodos como vibraciones de baja intensidad, campos electromagnéticos pulsados y terapia con láser de bajo nivel (LLLT). Se han realizado múltiples estudios sobre la eficacia de la LLLT en modelos animales, in vitro y en pacientes sin resultados concluyentes.

Objetivo: Evaluar el estado del arte en el uso de LLLT para aumentar la velocidad del movimiento dental ortodóncico para crear una guía de referencia concisa de los diferentes láser y protocolos disponibles. Materiales y métodos: Los autores buscaron en bases de datos electrónicas (MedLine, Scopus y Semantic Scholar) artículos que evaluaran los efectos de la terapia con láser de baja intensidad sobre el movimiento dental ortodóncico. La selección se realizó a nivel de título / resumen y texto completo. Dos revisores realizaron de forma independiente la extracción de datos y la evaluación de la calidad. También se examinaron las listas de referencias de estudios relevantes para obtener más literatura significativa.

Resultados: Encontramos información contradictoria en cuanto a la eficacia de la LLLT para acelerar el movimiento dental ortodóncico (OTM). No hay consenso sobre la forma en que se debe realizar la irradiación.

Conclusiones: La falta de un protocolo de irradiación estandarizado dificulta la comparación de resultados, incluso en los casos en que el láser tiene las mismas especificaciones técnicas.

PALABRAS CLAVE

LLLT; OTM; movimiento dental ortodóncico; láseres GaAlAs; aceleración. 


\section{Clinical relevance}

Scientific reasons for conducting the study. There is a lot of conflicting articles regarding the use of low-level laser therapy LLLT to accelerate the orthodontic tooth movement OTM, as well as an ever-increasing number of lasers, all claiming to have the right wavelength and power.

Main findings. There is a lack of standardization in the irradiation protocols, the efficacy of LLLT to accelerate the OTM is reported in a wide range of wavelengths, making it harder to discern which is the most effective protocol.

Practical implications. We urge the readers to review our chart to see the laser specs and protocols that more consistently reported gains in the rate of OTM, before acquiring a laser for their practice.

\section{Introduction}

The rate of tooth movement is an important factor in the duration of orthodontic treatment. This conventional treatment lasts about 2-3 years, this duration is linked to complications such as caries, root reabsorption, bone loss and non-compliance / abandonment of the patient. ${ }^{1,2}$ Therefore, accelerating the orthodontic tooth movement (OTM) would be beneficial for the treatment and the oral health of the patient.

In recent years, the methods that have been studied for the acceleration of dental movement include corticotomies, ${ }^{3}$ low intensity vibrations, ${ }^{4}$ pulsed electromagnetic fields, ${ }^{5}$ pharmacotherapy ${ }^{6}$ and low-level laser therapy (LLLT). ${ }^{7}$ There have been multiple studies on the efficacy of LLLT in animal models, ${ }^{8-11}$ in vitro and in patients, so we felt it necessary to review the current literature regarding the effect of LLLT in the OTM, with an emphasis on the most recent human trials.

\section{Materials and methods}

\section{Search criteria}

MedLine, Scopus and Semantic Scholar databases were searched for literature until April 2020. A lateral search from the reference lists of eligible articles was also conducted.

\section{Eligibility criteria}

The inclusion criteria for eligibility for this review included randomized clinical trials (RCTs), prospective and retrospective controlled clinical trials (CCTs) descriptive studies and review articles. The exclusion criteria for this review included case reports, case series, opinion pieces, abstracts only, and articles in languages other than English or Spanish. Eligible studies needed to focus their intervention on LLLT-accelerated OTM.
The results needed to be evaluated in comparison with a control group, be it either a discrete set of patients or a split mouth design in which each patient served as his or her control.

\section{The science behind the LLLT \& orthodontic tooth movement}

The LLLT consists in exposing tissue to low levels of red and/or near infrared light, it takes its name from the fact that these wavelengths are considered to have a lower energy density when contrasted with ablation, cauterizing or cutting lasers. This low-level energy density also produces less heat, reason what sometimes the LLLT is referred to as cold laser. 12

The precise mechanism underlying the effects of LLLT are not yet fully elucidated. It has a wide range of effects at the tissular, cellular and molecular levels. There is strong evidence suggesting that within the cell, at the mitochondria level the LLLT increases adenosine triphosphate (ATP) production and modulates reactive oxygen species (ROS). ${ }^{12,13}$

The LLLT acts by inducing a photochemical reaction in the cell. The photons from the laser are absorbed by chromophores inside the mitochondria of irradiated cells, electrons in the chromophores jump from a low-energy orbit to a higher-energy orbit. Thus, causes an increase in mitochondrial activity increasing production of ATP, NADH, proteins, and RNA, as well as an upregulation of cellular respiration all adding up to an increase in osteoclast genesis and with it, an increase in OTM. ${ }^{12}$

It's of particular importance for orthodontics the effect that the LLLT has on fibroblast, osteoblast and osteoclast, perhaps the 3 most important cells in the biomechanics of OTM. Multiple in vitro studies have found that LLLT increases the proliferation of human gingival fibroblast (HGF), basic fibroblast growth factor (bFGF), receptor of IGF-1 (IGFBP3) in HGF as well as insulin-like growth factor-1 (IGF-1) and the expression of collagen type I. ${ }^{1,14}$

Dominguez et al. 2008 evaluated the effects of LLLT on periodontal and gingival fibroblasts, the irradiation was done with a 832.79-nm 808nm Ga-Al-As diode laser (Photon Lase III ,DMC Equipamentos; São Carlos, Brazil) keeping the power outoput at $37-\mathrm{mW}$, continuous mode for $32.45 \mathrm{~s}$, resulting in a $3.75 \mathrm{~J} / \mathrm{cm}^{2}$ energy flow. After irradiation, the plates were incubated, a non-significant increase was observed in the irradiated group of both cell lines at 24, 48, 72, 96, 120, and 148-h post irradiation. Experimental and control groups had no statistically difference on cell viability. ${ }^{15}$

Similarly, albeit finding statistically significance, Kreisler et al. 2003 studied the effects of LLLT on the proliferation of human periodontal ligament fibroblast. 
A 809nm Ga-Al-As diode laser (Oralaser voxx, Oralia GmbH, 78467 Konstanz, Ger- many) keeping the power outoput at $10-\mathrm{mW}$, continuous mode for 75, 150 and 300 $\mathrm{s}$, resulting in a $1.96,3.92$ and $7.84 \mathrm{~J} / \mathrm{cm}^{2}$ energy flow respectively. They measured cell proliferation at 24,48 and $72 \mathrm{~h}$ after irradiation and found a higher cell proliferation on the experimental groups, the difference was significant up to $72 \mathrm{~h}$ after irradiation, at which point cell activity reached a peak in all groups, irrespective of the incubation time and irradiation regimen. ${ }^{16}$

This is consistent with Pereira et al. 2002 study, they used a 904-nm Ga-Al-As diode laser, the power output was set at $120-\mathrm{mW}$ during 8 and $24 \mathrm{~s}$, with a energy flow of 1 and $3 \mathrm{~J} / \mathrm{cm}^{2}$ respectively. They found that the irradiated groups of NIH-3T3 fibroblasts (CRL 1658 from American Type Culture Collection, Rockville, MD) had a significant increase of cell numbers compared to the control groups without impairing procollagen synthesis. ${ }^{17}$

Likewise Almeida et al. 2001 also found that LLLT improved the in vitro human gingival fibroblast proliferation with nutritional deficit and that shorter exposure times lead to higher proliferation. For this, they used 4 lasers, with wavelengths and power output of 670 $\mathrm{nm}$ at $10 \mathrm{~mW}, 780-\mathrm{nm}$ at $50-\mathrm{mW}, 692-\mathrm{nm}$ at $30-\mathrm{mW}$, and $786-\mathrm{nm}$ at $30-\mathrm{mW}$, manufacturers not disclosed. The energy flow was set at $2 \mathrm{~J} / \mathrm{cm}^{2}$ for all 4 lasers. Additionally, they found that the infrared laser $(780-\mathrm{nm})$ induced significantly higher cell growth than the visible laser (670 $\mathrm{nm})$ when set the same energy fluence $\left(2-\mathrm{J} / \mathrm{cm}^{2}\right) .{ }^{18}$

Aras et al. 2015 studied the effects of LLLT in an experimental rapid maxillary expansion model on female Wistar albino rats using an $808 \mathrm{~nm} \mathrm{Ga-Al-As} \mathrm{diode} \mathrm{laser}$ (Fotona XD-2 diode laser; Fotona, Ljubljana, Slovenia) applied with a $320 \mu \mathrm{m}$-diameter fiber handpiece. The rats were irradiated with $250 \mathrm{~mW}(0.25 \mathrm{~W})$ for $20 \mathrm{~s}$, totaling 5 $\mathrm{J} / \mathrm{cm}^{2}$. They found that the LLLT group had significantly higher numbers of osteoclast cells when compared with the control group. $(p=0.036)$ There was no difference in the number of osteoblast cells, however histological analysis revealed the trabecular bone was larger and better ossified in the LLLT group indicating that the healing process was more advanced. They concluded that histologically, LLLT stimulated bone formation. ${ }^{19}$

The effects of LLLT can also be seen on human cells, Khadra et al. 2005 studied the effects of LLLT on attachment, proliferation and differentiation of human osteoblast-like cells cultured on titanium implant material using an 830nm Ga-Al-As diode laser. (Rønvig Dental AS, Denmark) Each culture dish was irradiated with $84 \mathrm{~mW}$ at a dosage of 1.5 or $3 \mathrm{~J} / \mathrm{cm}^{2}$. They found no significant difference in the number of osteoblast cells at the $48 \mathrm{~h}$ and $72 \mathrm{~h}$ mark, but after $96 \mathrm{~h}$ the number of osteoblast cells in the irradiated group was significantly higher. $(\mathrm{p}<0.05)$ They also found no significant difference on cell viability between the irradiated and control group. ${ }^{20}$
However, significant difference in cell proliferation have observed as early as $24 \mathrm{~h}$ post irradiation, Dominguez et al. 2008 evaluated the effect of LLLT on Normal Human Osteoblast cells (NHOs from Cambrex Bioscience, Charles City, IA, USA) using a 832.79-nm Ga-Al-As diode laser (Photon LASE laser, DMC Equipamentos; Sao Carlos, Brazil). The irradiation was performed keeping the energy output at $36.73 \mathrm{~mW}$ in continuous mode for 1131 -s, resulting in an energy flow of $3.75 \mathrm{~J} / \mathrm{cm}^{2}$. They found that after the incubation periods $(24,48,72,96,120$, or $148-h$.), the proliferation of NHOs, in the experimental group was statistically significant until the $5^{\text {th }}$ day, when it reached contact inhibition. ${ }^{21}$

Sungsoo Na et al. 2018, studied the effect of LLLT on osteoblasts (MC3T3-E1,ATCC, Manassas, Virginia), osteocytes (MLO-A5), and osteoclasts (RAW264.7, ATCC, Manassas, Virginia) using a $940 \mathrm{~nm}$ custom-made device delivering doses of $0,1,5$, and $7.5 \mathrm{~J} / \mathrm{cm}^{2}$ After irradiation, cell activity was evaluated at 12,24 , and 48 -h, while cell viability was evaluated at 12 and $24 \mathrm{~h}$. They found that $24 \mathrm{~h}$ after a 10 minute low-dose treatment $\left(1 \mathrm{~J} / \mathrm{cm}^{2}\right.$ or $\left.1.67 \mathrm{~mW} / \mathrm{cm}^{2}\right)$ proliferation of osteoblasts was substantially increased $(\mathrm{p}<0.0001)$, and unlike the osteoclast, irradiation did not affect viability of osteoblast cells which may positively affect bone formation.

This research revealed that osteoclast differentiation mainly occurs with low-dose treatments. The increase peaked at $12 \mathrm{~h}$ $(\mathrm{p}<0.01)$ then it went down gradually until $48 \mathrm{~h}$ post irradiation, at which point it was no different than the control group. Their results suggest that low-dose treatment stimulates osteoblast and osteoclast differently, LLLT effect on osteoblast can be seen $24 \mathrm{~h}$ after laser application, whereas the effect on osteoclast can be seen as early as 12 h. ${ }^{22}$ It's $^{\prime}$ important to remark that this effect can no longer be seen after $48 \mathrm{~h}$ for either the osteoblast or the osteoclast, and the clinical implications that this may pose when designing the irradiation protocols.

\section{The evaluation of OTM and LLLT in human trials}

As stated before, the average treatment time is 2-3 years, up to 8 months of that time is often used during the leveling and alignment phase, which makes it an ideal phase to study the effects of laser in the OTM.

There have been multiple human trials to evaluate the efficacy of LLLT on the OTM, with varying and conflicting results. ${ }^{23-25}$ In one side there are multiple clinical trials that found that the LLLT significantly improved the rate of OTM during the leveling and alignment phase when compared with the control group (Table 1). AlSayed Hasan et al. 2017 evaluated the effect of LLLT during the leveling and alignment phase in cases with crowded maxillary incisors, using a 830nm laser device (CMS Dental ApS, 55 Wildersgade, 1408 Copenhagen K, Denmark), the irradiation was done on day $0,3,7$ and 14 for the first month and every 15 days from the $2^{\text {nd }}$ month onwards. 
Table 1. Summary of different studies where an effective protocol was used to accelerate the orthodontic movement.

\begin{tabular}{|c|c|c|c|c|c|c|c|c|c|c|}
\hline \multirow[b]{2}{*}{$\begin{array}{c}\text { First } \\
\text { Author } \\
\text { Publicatio } \\
\text { n. Year }\end{array}$} & \multirow[b]{2}{*}{$\mathbf{n}$} & \multicolumn{5}{|c|}{ Laser } & \multicolumn{3}{|c|}{ Application } & \multirow[b]{2}{*}{$\begin{array}{c}\text { Result } \\
\text { Velocity Vs } \\
\text { Control }\end{array}$} \\
\hline & & $\begin{array}{c}\text { Laser } \\
\text { type }\end{array}$ & $\begin{array}{l}\text { Wave } \\
\text { lenght }\end{array}$ & $\begin{array}{c}\text { Power, } \\
\text { Time }\end{array}$ & Dose $(\mathrm{J} / \mathrm{cm} 2)$ & $\begin{array}{c}\text { Total } \\
\text { Energy }(\mathbf{J})\end{array}$ & $\begin{array}{c}\text { Irradiation } \\
\text { Interval }\end{array}$ & $\begin{array}{l}\text { Applied } \\
\text { Tooth }\end{array}$ & $\begin{array}{c}\text { Force (g) / } \\
\text { Archsequence }\end{array}$ & \\
\hline $\begin{array}{l}\text { Cruz } \\
(2004)\end{array}$ & 11 & $\begin{array}{l}\text { Diode } \\
\text { Laser }\end{array}$ & $780 \mathrm{~nm}$ & $\begin{array}{c}20 \mathrm{~mW}, \\
10 \mathrm{~s}\end{array}$ & $5 \mathrm{~J} / \mathrm{cm}^{2}$ & $\begin{array}{c}\text { 0.2/Point } \\
\text { 2.0/Session }\end{array}$ & $\begin{array}{l}4 \text { days of each } \\
\text { month }\end{array}$ & Canine & $150 \mathrm{~g}$ & $\begin{array}{c}\text { Increase } 34 \% \\
\text { (2 Months) }\end{array}$ \\
\hline $\begin{array}{l}\text { Sousa } \\
\text { (2011) }\end{array}$ & 13 & $\begin{array}{l}\text { Diode } \\
\text { Laser }\end{array}$ & $780 \mathrm{~nm}$ & $\begin{array}{c}20 \mathrm{~mW}, \\
10 \mathrm{~s}\end{array}$ & $5 \mathrm{~J} / \mathrm{cm}^{2}$ & $\begin{array}{c}\text { 0.2/Point } \\
\text { 2.0/Session }\end{array}$ & $\begin{array}{c}\text { 0,3,7 Days of } \\
\text { each month }\end{array}$ & Canine & $150 \mathrm{~g}$ & $\begin{array}{l}2 x \text { Increase } \\
(4 \text { months })\end{array}$ \\
\hline $\begin{array}{l}\text { Genc } \\
(2013)\end{array}$ & 20 & $\begin{array}{l}\text { Diode } \\
\text { Laser }\end{array}$ & $808 \mathrm{~nm}$ & $\begin{array}{c}20 \mathrm{~mW} \\
10 \mathrm{~s}\end{array}$ & $0.71 \mathrm{~J} / \mathrm{cm}^{2}$ & $\begin{array}{c}\text { 0.2/Point } \\
2.0 / \text { Session }\end{array}$ & $\begin{array}{c}0,3,7,14,21,28 \\
\text { Days }\end{array}$ & $\begin{array}{c}\text { Upper } \\
\text { lateral } \\
\text { incisors }\end{array}$ & $80 \mathrm{~g}$ & $\begin{array}{l}20-40 \% \\
\text { Increase } \\
\text { (1 month) }\end{array}$ \\
\hline $\begin{array}{l}\text { Youssef } \\
\text { (2008) }\end{array}$ & 15 & $\begin{array}{l}\text { Diode } \\
\text { Laser }\end{array}$ & $809 \mathrm{~nm}$ & $\begin{array}{c}100 \mathrm{~mW} \\
10 / 20 \mathrm{~s}\end{array}$ & $8 \mathrm{~J} / \mathrm{cm}^{2}$ & 8.0/Session & 0,3,7,14 Days & Canine & $150 \mathrm{~g}$ & $\begin{array}{l}2 x \text { Increase } \\
(6 \text { months })\end{array}$ \\
\hline $\begin{array}{c}\text { Isola } \\
\text { (20019) }\end{array}$ & 41 & $\begin{array}{l}\text { Diode } \\
\text { laser }\end{array}$ & $810 \mathrm{~nm}$ & $1 \mathrm{~W}, 15 \mathrm{~s}$ & $66.7 \mathrm{~J} / \mathrm{cm}^{2}$ & $8 \mathrm{~J}$ & $\begin{array}{l}\text { Days } 3,7 \text {, and } \\
14 \text { days and } \\
\text { every } 15 \text { days } \\
\text { until the space } \\
\text { closed }\end{array}$ & Canine & $\begin{array}{l}\text { Force of } 50 / \mathrm{N} \\
\text { was applied by a } \\
\text { nickel-titanium } \\
\text { (NiTi) closed } \\
\text { coil spring }\end{array}$ & $\begin{array}{c}\text { A shorter } \\
\text { average time } \\
\text { to complete } \\
\text { space closure }\end{array}$ \\
\hline $\begin{array}{l}\text { Duan } \\
\text { (2012) }\end{array}$ & 44 & $\begin{array}{l}\text { Diode } \\
\text { Laser }\end{array}$ & $830 \mathrm{~nm}$ & $\begin{array}{c}180 \mathrm{~mW}, \\
4 \mathrm{~s}\end{array}$ & $3.6 \mathrm{~J} / \mathrm{cm}^{2}$ & $\begin{array}{l}\text { 18/ point } \\
54 / \text { session }\end{array}$ & Days $0,1,2$ & $\begin{array}{l}\text { Upper 1st } \\
\text { molar }\end{array}$ & 10 & Increase \\
\hline $\begin{array}{l}\text { AlSayed } \\
\text { Hasan } \\
(2017)\end{array}$ & 26 & $\begin{array}{l}\text { Ga-Al- } \\
\text { As }\end{array}$ & $830 \mathrm{~nm}$ & $\begin{array}{c}150 \mathrm{~mW}, \\
15 \mathrm{~s}\end{array}$ & $2.25 \mathrm{~J} / \mathrm{cm}^{2}$ & $2 \mathrm{~J} /$ point & $\begin{array}{c}\text { First month: } 4 \\
\text { (d } 0,3,7,14) ; \\
\text { starting from } \\
\text { the second } \\
\text { month: every } \\
15 \text { days }\end{array}$ & $\begin{array}{c}\text { Maxillary } \\
\text { incisors }\end{array}$ & $\begin{array}{c}\text { MBT } \\
\text { prescription and } \\
0.022 \text {-inch slot } \\
\text { height, the } \\
\text { archwire } \\
\text { sequence used } \\
\text { was } 0.014 \text {-inch } \\
\text { NiTi followed by } \\
0.01630 .016- \\
\text { inch and } 0.0173 \\
0.025 \text {-inch NiTi, } \\
\text { and finally } 0.019 \\
30.025 \text {-inch } \\
\text { stainless steel. }\end{array}$ & $26 \%$ increase \\
\hline
\end{tabular}

They found a statistically significant difference between the irradiated group $\left(150 \mathrm{~mW}, 2.25 \mathrm{~J} / \mathrm{cm}^{2}, 15 \mathrm{~s}\right)$ and the control group in the leveling and alignment improvement percentages at 1 month after the start of treatment $(69.41 \%$ vs $48.85 \%, \mathrm{P}=0.004)$ and 2 months $(89.42 \%$ vs $71.7 \%, \mathrm{p}=0.001)$ as well as in the overall treatment time $(\mathrm{p}<0.001){ }^{26}$

The purported benefits of the LLLT are not limited to the leveling and alignment phase, studies have shown an improvement in the OTM when retracting canines following premolars extractions. ${ }^{27-34}$
Da Silva Sousa et al. 2011 evaluated the effects of LLLT during canine retraction with a nitinol coil spring with a constant force of $150 \mathrm{~g}$, reactivated after 30 and 60 days. $3 \mathrm{D}$ casts were taken at $0,30,60$ and 90 days to measure the movement.

The irradiation was done with a 780nm Ga-Al-As diode laser (Twin Laser, MMOptics Ltda, Sao Carlos, Sao Paulo, Brazil) They found a statistically significant difference between the irradiated groups $\left(20 \mathrm{~mW}, 5 \mathrm{~J} / \mathrm{cm}^{2}, 10\right.$ s for 3 days) and the control groups. ${ }^{27}$ 
Genc et al. 2013 also evaluated the effect of LLLT on the rate of OTM during maxillary lateral retraction applying approximately $80 \mathrm{~g}$ of force with nickel-titanium closed coil springs and using an $808 \mathrm{~nm}$ Ga-Al-As diode laser (Fotona XD-2, USA) to perform the irradiation $(20 \mathrm{~mW}$, $0.71 \mathrm{~J} / \mathrm{cm}^{2}, 10 \mathrm{~s}$ ) on day $0,3,7,14,21$, and 28 days after the application of the nickel-titanium closed coil springs.

They found a statistically significant difference over time for the distances between the maxillary lateral incisors and the maxillary central incisors in comparison to the control group. ${ }^{35}$

Youssef et al. 2008 evaluated the effects of LLLT using an $809 \mathrm{~nm}$ Ga-Al-As diode laser (Quanta, Italy) during space closure. Canine retraction was done with prefabricated 16×16 Blue Elgiloy Ricketts Springs (RMO) delivering $150 \mathrm{~g}$ of force reactivated ever 21 days until space closure was achieved. The canines were irradiated $(100 \mathrm{~mW}, 8$ $\mathrm{J} / \mathrm{cm}^{2}, 2 \times 40 \mathrm{~s}$ ) on days $0,3,7$, and 14 after every activation. They reported an analgesic effect and a significantly increase in the rate of OTM during space closure when compared with the control group. ${ }^{28}$

Yassaei et al. 2016 used a $980 \mathrm{~nm} \mathrm{Ga-Al-As} \mathrm{diode} \mathrm{laser}$ (A.R.C. Laser GmbH, Nürnberg, Germany) to irradiate $\left(100 \mathrm{~mW}, \quad 5.6 \mathrm{~J} / \mathrm{cm}^{2}, 56 \mathrm{~s}\right)$ the tooth during canine retraction, closed coil springs with a $150 \mathrm{~g}$ force were used for the retraction on rectangular wires.

A light but not statistically significant improvement in the rate of retraction was observed, additionally the mean concentration of IL- 6 was measured, finding there was no significant difference in the mean concentration of IL-6 between the groups during canine distalization and thus they could not provide conclusive evidence to support its efficacy. ${ }^{29}$

Cruz et al. 2004 evaluated the effects of LLLT during canine retraction. A 12-mm Nickel-Titanium closed-loop coil spring exhorting $150 \mathrm{~g}$ of force was used for the retraction. The irradiation was done with a 780nm Ga-AlAs diode laser (Twin Laser, MM Optics Ltda., Sao Carlos, $\mathrm{SP}$, Brazil) ,the canines were irradiated $\left(20 \mathrm{~mW}, 5 \mathrm{~J} / \mathrm{cm}^{2}\right.$, $10 \mathrm{x} 10 \mathrm{~s})$ by the same operator, 5 points on buccal side and 5 by the palatal side.

A significantly higher rate of OTM was observed on the irradiation group. The accelerated OTM was achieved with a healthy response from periodontal tissue as confirmed by the radiographic images that showed no evidence of damage in the dental and periodontal tissue of the irradiated teeth. ${ }^{30}$
Dominguez et al. 2015 evaluated the effect of the LLLT with a $670 \mathrm{~nm}$ laser (Periowave ${ }^{\mathrm{TM}}$, Ondine Biopharma Corporation, Vancouver, Canada) the irradiation (200 $\mathrm{mW}, 6.37 \mathrm{~W} / \mathrm{cm}^{2}, 540 \mathrm{~s}$ on days $0,1,2,3,4$, and 7) was done on the distal, buccal, and lingual side of the premolar for $3 \mathrm{~m}$ on each side for a total of $9 \mathrm{~m}$.

For the space closure, the first bicuspids were distalized with a nitinol coil spring with a constant force of $150 \mathrm{~g}$, they found a slight improvement in the rate of OTM, after 30 days, the accumulated retraction was statistically significant. ${ }^{36}$

Doshi-Mehta et al. 2011 evaluated the effect of LLLT during individual canine retraction by a nickel-titanium closed-coil. The laser used was an 800nm Ga-Al-As diode laser (LA3D0001.1; LAMBDA S.p.A., Vicenza, Italy) and the irradiation $\left(100 \mathrm{~mW}, 5 \mathrm{~J} / \mathrm{cm}^{2}, 80 \mathrm{~s}\right)$ for bio-stimulation started 3 days after the nickel-titanium coil spring placement. The average time for complete canine retraction on the irradiated side was 4.5 months, showing a $30 \%$ higher OTM rate when compared with the control side. $^{31}$

Qamruddin et al. 2017 evaluated the effects of LLLT during canine retraction using MBT self-ligating brackets. To retract the canines $6 \mathrm{~mm}$ nickel-titanium closed-coil springs were used, exerting a constant retraction force of 150g. A 940nm Ga-Al-As diode laser (iLas; Bio- lase, Irvine, Calif) was used to irradiate $\left(100 \mathrm{~mW}, 7.5 \mathrm{~J} / \mathrm{cm}^{2}, 30 \mathrm{~s}\right.$ every 3 weeks) the canines on 10 points, 2 seconds per point.

The distance was measured digitally with $\mathrm{CAD} / \mathrm{CAM}$ scanned models. A statistically significantly increase in the rate of canine retraction was observed, the rate on the experimental side was 2.02 times greater compared with the placebo side, thus it was concluded that LLLT can double the rate of OTM when applied in intervals of 3 weeks. ${ }^{32}$

Varella et al. 2018 evaluated the effects of LLLT with a similar 940nm Ga-Al-As diode laser (Ezlase; BIOLASE Technology, Irvine, Calif) during canine retraction with a light nickel-titanium closed coil spring (9x12mm) exerting $150 \mathrm{~g}$ of force between the canines and the first bicuspids. They also found a significant increase in the rate of OTM on the irradiated group $\left(100 \mathrm{~mW}, 8 \mathrm{~J} / \mathrm{cm}^{2}, 10 \times 10 \mathrm{~s}\right)$, twice that of the control group. ${ }^{33}$

Isola et al. 2019 evaluated the effects of LLLT with an 810nm (Wiser Laser Doctor Smile, Brendola, Italy) during canine distalization using an orthodontic force of $50 / \mathrm{N}$ applied with a nickel-tatanium closed coil spring using a split-mouth design. 
Table 2. Summary of studies where an effective protocol was used to accelerate the orthodontic movement.

\begin{tabular}{|c|c|c|c|c|c|c|c|c|c|}
\hline \multirow[b]{2}{*}{$\begin{array}{l}\text { First Author } \\
\text { Publication. } \\
\text { Year }\end{array}$} & \multirow[b]{2}{*}{$\mathbf{n}$} & \multicolumn{4}{|c|}{ Laser } & \multicolumn{3}{|c|}{ Application } & \multirow[b]{2}{*}{$\begin{array}{c}\text { Result Velocity Vs } \\
\text { Control }\end{array}$} \\
\hline & & Laser type & $\begin{array}{l}\text { Wave } \\
\text { lenght }\end{array}$ & $\begin{array}{l}\text { Power, } \\
\text { Time }\end{array}$ & $\begin{array}{c}\text { Dose } \\
\left(\mathrm{J} / \mathrm{cm}^{2}\right)\end{array}$ & $\begin{array}{c}\text { Irradiation } \\
\text { interval }\end{array}$ & $\begin{array}{l}\text { Applied } \\
\text { tooth }\end{array}$ & $\begin{array}{c}\text { Force (g) / } \\
\text { Archsequence }\end{array}$ & \\
\hline $\begin{array}{l}\text { Heravi } \\
(2014)\end{array}$ & 20 & $\begin{array}{l}\text { Go- } \\
\text { Al- As }\end{array}$ & $810 \mathrm{~nm}$ & 30 secs & $\begin{array}{c}21.4 \\
\mathrm{~J} / \mathrm{cm}^{2}\end{array}$ & $\begin{array}{c}\text { Days } 3,7,11,15 \\
\text { over the first } \\
\text { month }\end{array}$ & Canine & $\begin{array}{l}\text { Distalizing with a nitinol } \\
\text { coil spring with a } \\
\text { constant force of } 150 \mathrm{~g}\end{array}$ & $\begin{array}{l}\text { No significant } \\
\text { difference on the } \\
\text { rate of OTM }\end{array}$ \\
\hline $\begin{array}{l}\text { Limpanichkul } \\
\text { (2006) }\end{array}$ & 12 & Diode laser & $860 \mathrm{~nm}$ & $\begin{array}{c}100 \mathrm{~mW}, \\
23 \mathrm{~s}\end{array}$ & $25 \mathrm{~J} / \mathrm{cm}^{2}$ & $\begin{array}{l}\text { First } 3 \text { days of } \\
\text { each month }\end{array}$ & Canine & $150 \mathrm{~g}$ & No effect \\
\hline $\begin{array}{l}\text { Dalaie } \\
(2015)\end{array}$ & 12 & $\begin{array}{l}\text { Ga-Al-As } \\
\text { diode laser }\end{array}$ & $880 \mathrm{~nm}$ & $\begin{array}{r}100 \mathrm{~mW}, \\
80 \mathrm{~s}\end{array}$ & $5 \mathrm{~J} / \mathrm{cm}^{2}$ & $\begin{array}{l}\text { Days } 1,3,7,30 \\
33,37,60,63 \\
\text { and } 67\end{array}$ & Canine & $\begin{array}{c}\text { Force } 150 \mathrm{~g} \text { was applied } \\
\text { to each canine tooth via } \\
\text { sectional closing loops } \\
(16 \times 22 \text { steel wire })\end{array}$ & $\begin{array}{l}\text { No stastically } \\
\text { significant } \\
\text { difference }\end{array}$ \\
\hline $\begin{array}{l}\text { Kansal } \\
\text { (2014) }\end{array}$ & 10 & $\begin{array}{l}\text { Gallium- } \\
\text { Arsenide } \\
\text { laser }\end{array}$ & $904 \mathrm{~nm}$ & $\begin{array}{c}12 \mathrm{~mW}, \\
10 \mathrm{~s}\end{array}$ & $4.2 \mathrm{~J} / \mathrm{cm}^{2}$ & $\begin{array}{c}\text { Days } 1,3,7,14, \\
21,28,35,42, \\
49,56\end{array}$ & Canine & $\begin{array}{l}\text { MBT prescription- } 0.022 \\
\text { slot, force } 150 \mathrm{~g}, 19 \times 25 \\
\text { SS }\end{array}$ & $\begin{array}{l}\text { No stastically } \\
\text { significant } \\
\text { difference }\end{array}$ \\
\hline $\begin{array}{l}\text { Yassaei } \\
\text { (2016) }\end{array}$ & 11 & $\begin{array}{l}\text { Ga-Al-As } \\
\text { laser Diode } \\
\text { laser }\end{array}$ & $980 \mathrm{~nm}$ & $\begin{array}{c}100 \mathrm{~mW}, \\
56 \mathrm{~s}\end{array}$ & $5.6 \mathrm{~J} / \mathrm{cm}^{2}$ & $\begin{array}{l}\text { Days } 0,7,14,21 \text {, } \\
\text { and } 28 \text { of each } \\
\text { month during the } \\
\text { canine retraction }\end{array}$ & $\begin{array}{l}\text { Maxillary } \\
\text { canine }\end{array}$ & $\begin{array}{l}150 \mathrm{~g} . \text { A preadjusted } \\
0.022 \times 0.028^{\prime \prime} \text { edgewise } \\
\text { appliance was used for } \\
\text { bonding and a } \\
\text { transpalatal bar, NiTi } \\
\text { closed coil springs on } \\
\text { rectangular SS wire }\end{array}$ & $\begin{array}{l}\text { No stastically } \\
\text { significant } \\
\text { difference }\end{array}$ \\
\hline
\end{tabular}

A shorter average time to complete space closure was observed on the irradiated $\left(100 \mathrm{~mW}, 66.7 \mathrm{~J} / \mathrm{cm}^{2}, 15 \mathrm{~s}, 8 \mathrm{~J}\right)$ side compared to the control side. ${ }^{34}$ On the other side we have an equally important number of clinical trials that found that the LLLT does not improve the rate of OTM (Table 2).

Dalaie et al. 2015 evaluated the effect of LLLT on the OTM during space closure with loops, using a 810nm laser (Wiser Laser Doctor Smile, Lambda, Brendola, Italy) finding no significant difference between the irradiated group (100 $\mathrm{mW}, 5 \mathrm{j} / \mathrm{cm}^{2}, 80 \mathrm{~s}$ ) and the control group. ${ }^{37}$

Heravi et al. 2014 evaluated the use of LLLT during canine retraction, with an $810 \mathrm{~nm}$ Ga-Al-As diode laser, finding there was no significant difference on the rate of OTM or its degree of mesiodistal inclination between the irradiated $\left(200 \mathrm{~mW}, 21.4 \mathrm{~J} / \mathrm{cm}^{2}, 30 \mathrm{secs}\right)$ and control group. ${ }^{38}$

Limpanichkul et al. 2006 is another study where the LLLT during canine retraction using a $860 \mathrm{~nm}$ Ga-Al-As diode laser (Top Laser 250 SIR 100, Medical Innovation, France) failed to produce an increase in the rate of OTM, the authors believe the energy density in their protocol $(100 \mathrm{~mW}$, $25 \mathrm{~J} / \mathrm{cm}^{2}, 8 \times 23 \mathrm{~s}$ ) was too low to induce any biological effect on the OTM. ${ }^{39}$
Similarly Kansal et al. 2014 found that there was no statistically significant difference in the rate of OTM during canine retraction using a 904nm Ga-Al-As diode laser (ORALIA Dental Products, D-7750 Konstanz, Germany) between the irradiated group $(12 \mathrm{~mW}$, $4.2 / \mathrm{cm}^{2}, 10 \times 10 \mathrm{~s}$ ) and the control group. ${ }^{40}$

\section{Conclusions}

The varying and conflicting results can be explained by the equally diverse LLLT protocols used by each study. There is a broad range of laser types, laser colors, wavelengths, power levels, exposure times, doses and application methodology that vary from study to study.

More studies need to be done to assess the efficacy of LLLT in accelerating the OTM. The authors remark the need for a more technical approach when categorizing the lasers used in the LLLT and their effects in OTM, as well as the need to come up with a standardized point of application protocol, as it stands right now, every clinician irradiates the teeth as they see fit, making it impossible to compare their results with studies that used the same laser, but different protocol and vice versa. 


\section{Statement of Conflict of interest and waiver}

All authors of the manuscript declare that they do not have competing financial interests or personal relationships that could have appeared to influence the work reported in this paper.

\section{Information on Financing}

This project was financed by the Consejo Nacional de Ciencia y Tecnología (CONACYT).

\section{Acknowledgment}

We would like to thank the coordinator of our postgraduate course, M.O. Laura Monica Lopez Perez-Franco, as well as the Consejo Nacional de Ciencia y Tecnología (CONACYT) for the scholarship granted during this period.

\section{References}

1. Kim SJ, Chou MY, Park YG. Effect of low-level laser on the rate of tooth movement. Semin Orthod [Internet]. 2015;21(3):210-8. doi:10.1053/j.sodo.2015.06.008

2. Haliloglu Ozkan T, Arıcı S, Özkan E. Acceleration of Orthodontic Tooth Movement: An Overview. Anadolu Klin Tip Bilim Derg [Internet]. 2018 May 20;23(2):121-8. doi:10.21673/anadoluklin.378727

3. Patterson BM, Dalci O, Darendeliler MA, Papadopoulou AK Corticotomies and Orthodontic Tooth Movement: A Systematic Review. J Oral Maxillofac Surg [Internet]. 2016;74(3):453-73. doi:10.1016/j.joms.2015.10.011

4. Jing D, Xiao J, Li X, Li Y, Zhao Z. The effectiveness of vibrational stimulus to accelerate orthodontic tooth movement: a systematic review. BMC Oral Health [Internet]. 2017 Dec 1;17(1): 143 . doi:10.1186/s12903-017-0437-7

5. Stark TM, Sinclair PMs. Effect of pulsed electromagnetic fields on orthodontic tooth movement. Am J Orthod Dentofac Orthop [Internet]. $1987 \quad$ Feb;91(2):91-104. doi:10.1016/0889-5406(87)90465-3

6. Yamasaki K, Shibata Y, Imai S, et al. Clinical application of prostaglandin E1 (PGE1) upon orthodontic tooth movement. Am J Orthod [Internet]. 1984 Jun;85(6):508-18. doi:10.1016/00029416(84)90091-5

7. Long H, Zhou Y, Xue J, et al. The effectiveness of low-level laser therapy in accelerating orthodontic tooth movement: a meta-analysis. Lasers Med Sci [Internet]. 2015 Apr 11;30(3):1161-70. doi:10.1007/s10103-013-1507-y

8. Yamaguchi M, Hayashi M, Fujita S, et al. Low-energy laser irradiation facilitates the velocity of tooth movement and the expressions of matrix metalloproteinase-9, cathepsin $\mathrm{K}$, and alpha(v) beta(3) integrin in rats. Eur J Orthod [Internet]. 2010 Apr $1 ; 32(2): 131-9$ doi:10.1093/ejo/cjp078

9. Lirani-Galvão AP, Jorgetti V, Da Silva OL. Comparative Study of How Low-Level Laser Therapy and Low-Intensity Pulsed Ultrasound Affect Bone Repair in Rats. Photomed Laser Surg [Internet]. $2006 \quad$ Dec;24(6):735-40. doi:10.1089/pho.2006.24.735

10. Kawasaki K, Shimizu N. Effect of low-energy laser irradiation on bone formation during experimental tooth movement in rats. J JAPAN Soc LASER Surg Med [Internet]. 1999;20(3):215-22. doi:10.2530/jslsm1980.20.3_215

11. Ueda Y, Shimizu N. Effects of Pulse Frequency of Low-Level Laser Therapy (LLLT) on Bone Nodule Formation in Rat Calvarial Cells. J Clin Laser Med Surg [Internet]. 2003 Oct:21(5):271-7. doi: $10.1089 / 104454703322564479$

12. B Cotler H. The Use of Low Level Laser Therapy (LLLT) For Musculoskeletal Pain. MOJ Orthop Rheumatol [Internet]. 2015 Jun 9;2(5):139-48.

doi:10.15406/mojor.2015.02.00068

3. León P, Domínguez A. Laser therapy and biochemical markers in the acceleration of orthodontic dental movement: a review of the literature. Rev Estomatol [Internet]. 2017 Sep 29;21(2):2631.

doi:10.25100/re.v21i 2.5763

14. Saygun I, Karacay S, Serdar M, et al. Effects of laser irradiation on the release of basic fibroblast growth factor (bFGF), insulin like growth factor-1 (IGF-1), and receptor of IGF-1 (IGFBP3) from gingival fibroblasts. Lasers Med Sci [Internet]. 2008 Apr 10;23(2):211-5.

doi:10.1007/s10103-007-0477-3

15. Domínguez A, Clarkson A, Lopez R. An In Vitro Study of the Reaction of Periodontal and Gingival Fibroblasts to Low-level Laser Irradiation: A Pilot Study. J Oral Laser Appl [Internet]. 2008;8(January 2008):235-44. CorpusID:26882534

16. Kreisler M, Christoffers AB, Willershausen B, D'Hoedt B. Effect of low-level GaAlAs laser irradiation on the proliferation rate of human periodontal ligament fibroblasts: an in vitro study. J Clin Periodontol [Internet]. 2003 Apr;30(4):353-8. doi:10.1034/j.1600-051X.2003.00001.x

17. Pereira AN, Eduardo C de P, Matson E, Marques MM. Effect of low-power laser irradiation on cell growth and procollagen synthesis of cultured fibroblasts. Lasers Surg Med [Internet]. 2002

Oct:31(4):263-7. doi: $10.1002 / 1 \mathrm{sm} .10107$

18. Almeida-Lopes L, Rigau J, Amaro Zângaro R, Guidugli-Neto J, Marques Jaeger MM. Comparison of the low level laser therapy effects on cultured human gingival fibroblasts proliferation using different irradiance and same fluence*. Lasers Surg Med [Internet]. $2001 \quad$ Aug;29(2):179-84. doi: $10.1002 / 1 \mathrm{sm} .1107$

19. Aras M, Erkilic S, Demir T, et al. Effects of low-level laser therapy on osteoblastic bone formation and relapse in an experimental rapid maxillary expansion model. Niger $\mathbf{J}$ Clin Pract [Internet]. 2015;18(5):607. doi:10.4103/1119-3077.154218

20. Khadra M, Lyngstadaas SP, Haanæs HR, Mustafa K. Effect of laser therapy on attachment, proliferation and differentiation of human osteoblast-like cells cultured on titanium implant material. Biomaterials [Internet]. 2005;26(17):3503-9. doi:10.1016/j.biomaterials.2004.09.033

21. Domínguez A, Clarkson A, Lopez R. An In Vitro Study of the Reaction of Human Osteoblasts to low-level Laser Irradiation. J Oral Laser Appl [Internet]. 2008;8(January 2008):235-44. Corpus ID: 138543500

22. Na S, TruongVo T, Jiang F, et al. Dose analysis of photobiomodulation therapy on osteoblast, osteoclast, and osteocyte. J Biomed Opt [Internet]. 2018;23(07):1. doi:10.1117/1.JBO.23.7.075008

23. Ge MK, He WL, Chen J, et al. Efficacy of low-level laser therapy for accelerating tooth movement during orthodontic treatment: a systematic review and meta-analysis. Lasers Med Sci [Internet]. 2015;30(5):1609-18. doi:10.1007/s10103-014-1538-z

24. Deana NF, Zaror C, Sandoval P, Alves N. Effectiveness of LowLevel Laser Therapy in Reducing Orthodontic Pain: A Systematic Review and Meta-Analysis. Pain Res Manag [Internet].

2017;2017. 
doi:10.1155/2017/8560652

25. Maria Wilson T, Jain S. Effects of Low Level Laser Therapy on Orthodontic Tooth Movement: A Systematic Review. J Orthod Endod [Internet]. 2018;04(04):1-7. doi:10.21767/2469-2980.100064

26. AlSayed Hasan MMA, Sultan K, Hamadah O. Low-level laser therapy effectiveness in accelerating orthodontic tooth movement: A randomized controlled clinical trial. Angle Orthod [Internet]. doi: $10.2319 / 062716-503.1$

27. Da Silva Sousa MV, Scanavini MA, Sannomiya EK, Velasco LG, Angelieri F. Influence of low-level laser on the speed of orthodontic movement. Photomed Laser Surg [Internet]. 2011;29(3):191-6.

doi: $10.1089 /$ pho.2009.2652

28. Youssef M, Ashkar S, Hamade E, et al. The effect of low-level laser therapy during orthodontic movement: A preliminary study. Lasers Med Sci [Internet]. 2008;23(1):27-33. doi:10.1007/s10103-007-0449-7

29. Yassaei S, Aghili H, Afshari JT, Bagherpour A, Eslami F. Effects of diode laser $(980 \mathrm{~nm})$ on orthodontic tooth movement and interleukin 6 levels in gingival crevicular fluid in female subjects. Lasers Med Sci [Internet]. 2016;31(9):1751-9. doi:10.1007/s10103-016-2045-1

30. Cruz DR, Kohara EK, Ribeiro MS, Wetter NU. Effects of lowintensity laser therapy on the orthodontic movement velocity of human teeth: A preliminary study. Lasers Surg Med [Internet]. 2004;35(2):117-20.

doi: $10.1002 / 1 \mathrm{sm} .20076$

31. Doshi-Mehta G, Bhad-Patil WA. Efficacy of low-intensity laser therapy in reducing treatment time and orthodontic pain: A clinical investigation. Am J Orthod Dentofac Orthop [Internet]. 2012;141(3):289-97.

doi:10.1016/j.ajodo.2011.09.009

32. Qamruddin I, Alam MK, Mahroof V, et al. Effects of low-leve laser irradiation on the rate of orthodontic tooth movement and associated pain with self-ligating brackets. Am J Orthod Dentofac Orthop [Internet]. 2017;152(5):622-30 doi:10.1016/j.ajodo.2017.03.023

33. Varella AM, Revankar A V, Patil AK. Low-level laser therapy increases interleukin-1 $\beta$ in gingival crevicular fluid and enhances the rate of orthodontic tooth movement. Am J Orthod Dentofac Orthop [Internet]. 2018;154(4):535-544.e5. doi:10.1016/j.ajodo.2018.01.012

34. Isola G, Matarese M, Briguglio F, et al. Effectiveness of lowlevel laser therapy during tooth movement: A randomized clinical trial. Materials (Basel) [Internet]. 2019;12(13):1-12. doi: $10.3390 / \mathrm{ma} 12132187$

35. Genc G, Kocadereli I, Tasar F, et al. Effect of low-level laser therapy (LLLT) on orthodontic tooth movement. Lasers Med Sci [Internet]. $2013 ; 28(1): 41-7$ doi:10.1007/s10103-012-1059-6

36. Domínguez A, Gómez C, Palma JC. Effects of low-level laser therapy on orthodontics: rate of tooth movement, pain, and release of RANKL and OPG in GCF. Lasers Med Sci [Internet]. 2015;30(2):915-23.

doi:10.1007/s10103-013-1508-x

37. Dalaie K, Hamedi R, Kharazifard MJ, Mahdian M, Bayat M. Effect of Low-Level Laser Therapy on Orthodontic Tooth Movement: A Clinical Investigation. J Dent (Tehran) [Internet]. 2015;12(4):249-56. PMID:26622279

38. Heravi F, Moradi A, Ahrari F. The effect of low level laser therapy on the rate of tooth movement and pain perception during canine retraction. Oral Health Dent Manag [Internet]. 2014 PMID:24984620

39. Limpanichkul W, Godfrey K, Srisuk N, Rattanayatikul C. Effects of low-level laser therapy on the rate of orthodontic tooth movement. Orthod Craniofacial Res [Internet]. 2006;9(1):3843. doi:10.1111/j.1601-6343.2006.00338.x

40. Kansal A, Kittur N, Kumbhojkar V, Keluskar KM, Dahiya P. Effects of low-intensity laser therapy on the rate of orthodontic tooth movement: A clinical trial. Dent Res J (Isfahan) [Internet]. 2014 Jul;11(4):481-8.PMID:25225562 